\title{
Some morphological parallels between Hokan languages ${ }^{1}$
}

\begin{abstract}
In this paper I present a detailed analysis of a number of morphological comparisons between the branches of the hypothetical Hokan family. The following areas are considered: 1) subject person/number markers on verbs, as well as possessor person/number markers on nouns, 2) so-called 'lexical prefixes' denoting instrument and manner of action on verbs, 3) plural infixes, used with both nouns and verbs, and 4) verbal directional suffixes 'hither' and 'thither'. It is shown that the respective morphological parallels can be better accounted for as resulting from genetic inheritance rather than from areal diffusion.
\end{abstract}

Keywords: Hokan languages, Amerindian languages, historical morphology, genetic vs. areal relationship

0. The Hokan hypothesis, relating several small language families and isolates of California, was initially proposed by Dixon and Kroeber (1913) more than a hundred years ago. There is still no consensus regarding the validity of Hokan: some scholars accept the hypothesis (Kaufman 1989, 2015; Gursky 1995), while others view it with great skepticism (Campbell 1997: 290-296, Marlett 2007; cf. a more positive assessment in Golla 2011: 82-84, as well as a neutral overview in Jany 2016). My own position is that the genetic relationship between most languages usually subsumed under Hokan is highly likely, and that the existence of the Hokan family can be taken as a working hypothesis, subject to further proof or refutation.

The goal of the present paper is to draw attention to several morphological parallels between Hokan languages. Some of these comparisons are new (e.g., third person possessive prefix on kinship terms in Seri and Salinan in section 1.2., lexical prefix 'with the whole body' in section 2.8., plural infixes in Oaxaca Chontal, Seri and Pomoan in sections 3.2., 3.4. and 3.5.), others have been proposed earlier. While many works by proponents of Hokan concentrate on lexical comparisons, comparative morphology drew much less attention. The main works in this area are Sapir 1925 (a pioneering study with many valuable insights, although based on the erroneous premise of the Hokan nature of the Subtiaba language which was later shown to belong to the Otomanguean family), Gursky 1966 (compares Hokan morphology with that of the so-called Gulf languages), Gursky 1995 (an extremely useful list of 138 morphological comparisons with supporting data, but without reconstructions) and Kaufman 2015 (a slightly revised version of an unpublished study written in 1989; contains a tentative model of ProtoHokan word-structure and a large list of reconstructed grammatical morphemes without supporting data). Nowadays, we have much more abundant and detailed descriptive data for many languages under discussion, so existing comparisons require re-evaluation in the light of these data. This paper will concentrate on several areas where good comparisons can be

${ }^{1}$ I am sincerely grateful to Albert Davletshin, Vasiliy Chernov, and two anonymous reviewers for numerous corrections and suggestions that helped me to improve this paper. None of them is responsible for any remaining errors. I express my sincere gratitude to Søren Wichmann who generously helped me to obtain several rare publications on the subject. This research has been carried out as part of the Evolution of Human Languages project, supported by the Santa Fe Institute.

Journal of Language Relationship • Вопросы языкового родства • 16/2 (2018) • Pp. 138-161 • ( ) The authors, 2018 
found: person and number markers, lexical prefixes, plural infixes, and directional suffixes. There are other areas requiring work: plural suffixes and prefixes, TAM markers, stative and passive markers, nominalizers, etc. These could not be covered here because of space and time limitations. One must not draw the conclusion that the list of morphological comparisons in the present paper is exhaustive.

For the purposes of the present paper, the following languages and families will be regarded as Hokan: Karuk, Chimariko, Shastan, Achumawi-Atsugewi (Palaihnihan), Yana, Pomoan, Salinan, Yuman, Seri, and Oaxaca Chontal (Tequistlatecan). I suspend my judgment with regard to poorly attested languages/families like Esselen, Coahuilteco, Comecrudoan and Cotoname. Another poorly documented language, Cochimi, is generally considered as related to Yuman (Mixco 1978). Following Kaufman (1989), I do not accept a Hokan affiliation of Chumashan. I also do not include Washo and Tol (Jicaque), although these languages might be related to Hokan on a deeper level. Washo was regarded as Hokan by virtually all supporters of the Hokan hypothesis. However, it has so few reliable matches with the rest of Hokan in the basic lexicon that its membership in the Hokan family seems improbable. If Washo and/or Tol will ever be shown to be related to Hokan, it will only be through comparison with reliable ProtoHokan reconstructions, rather than with isolated morphemes in individual Hokan languages.

While reconstructing tentative Proto-Hokan forms, I will use the system of sound correspondences proposed by Kaufman (1989: 84-93).

\section{Person/number markers}

1.1. In Seri, finite verbs show the following subject inflection prefixes ${ }^{2}$ (Marlett 2016: 420):

\begin{tabular}{|c|c|c|}
\hline & sg. & pl. \\
\hline 1 & $\begin{array}{c}\text { 3- (transitive), } \\
\text { 3p- (intransitive) }\end{array}$ & ?a- \\
\hline 2 & m- & ma- \\
\hline 3 & i- $\left(3^{\text {rd }}\right.$ person subject $+3^{\text {rd }}$ & object) \\
\hline
\end{tabular}

This paradigm is strikingly similar to the paradigm of subject inflection reconstructed for Proto-Yuman (Hinton \& Langdon 1976: 120): *?- 'first person', ‘ $m$ - 'second person', * $\varnothing$ - 'third person'3. While $m$ - as second person marker is widespread in the Americas (Zamponi 2017), the pronominal paradigm $2-/ m-/ \varnothing$ - is not. Remarkably, a similar paradigm is found in Chimariko, a Hokan language geographically distant from both Seri and Yuman. Chimariko verbal suffixes for singular agent are $-2(i)$ 'first person', $-m(V)$ 'second person' and $-h / \varnothing$ 'third person' (Jany 2009: 100). There are six verbal stem classes depending on the initial segment of the stem: $a$-stems, $e$-stems, $i$-stems, $o$-stems, $u$-stems and consonantal stems (Jany 2009: 33). Consonantal stems, i.e. stems beginning with a consonant, take suffixed person markers, while stems beginning with a vowel take person prefixes, which interact in a complex way with the stem vowel (Jany 2009: 100). The following table shows Chimariko person prefixes for agent:

2 All data in this paper are in the Americanist transcription system.

${ }^{3}$ The comparison between Seri and Proto-Yuman forms was proposed by M. Langdon (Marlett 2007). 


\begin{tabular}{c|c|c|c|c|c}
\hline & i-stem & e-stem & a-stem & o-stem & u-stem \\
\hline 1 sg. & 2i- & ye- & ye- & yo- & yu- \\
\hline 2 sg. & mi- & me- & ma- & mo- & mu- \\
\hline 3 sg. & hi- & he- & ha- & ho- & hu- \\
\hline 1 pl. & ya- & ya- & ya- & ya- & ya- \\
\hline 2 pl. & q $^{\mathrm{h}} \mathrm{y}^{-}$ & $\mathrm{q}^{\mathrm{h}} \mathrm{o}-$ & $\mathrm{q}^{\mathrm{h}} \mathrm{a}-$ & $\mathrm{q}^{\mathrm{h}} \mathrm{o}-$ & $\mathrm{q}^{\mathrm{h}} \mathrm{u}-$ \\
\hline $3 \mathrm{pl}$. & hi- & he- & ha- & ho- & hu- \\
\hline
\end{tabular}

We can posit the underlying forms of agent prefixes * $y$ - ' 1 sg.', * $m$ - '2 sg.', * $h$ - ' $3 \mathrm{sg} . / \mathrm{pl}$. ', *ya- ' 1 pl.' and * $q^{h} u$ - '2 pl.'. Then the following morphophonological rules will yield the observed forms of the prefixes: ${ }^{*} y+i-\rightarrow\left\{i-,{ }^{*} y+a \rightarrow\right.$ ye (before consonants) / ya (before vowels), ${ }^{*} a+V \rightarrow a,{ }^{*} u+i / u \rightarrow u,{ }^{*} u+e / o \rightarrow o,{ }^{*} u+a \rightarrow a$. Sapir, who first suggested this analysis of Chimariko forms, noted their similarity with the markers of person in another Hokan language, Salinan (Sapir 1920a). Salinan has the following verbal subject markers (Turner 1987: 129):

\begin{tabular}{c|c|c}
\hline & sg. & pl. \\
\hline 1 & -ek & -ak \\
\hline 2 & m- & k- \\
\hline 3 & -o? & $\varnothing$ \\
\hline
\end{tabular}

According to Turner, " $[w]$ hatever the first vowel of the verb stem, it is replaced by a in the first person plural and by o in the second person plural" (ibid.). So, Chimariko and Salinan have in common not only second person singular in $m$ - and second person plural in velar/uvular ${ }^{4}$, but also vowels that replace (or merge with) the stem vowel: first person plural $a$ and second person plural $u / o^{-}$.

Let us have another look at Seri: the first person plural prefix $2 a-$ (opposed to the first person singular 2-) in this language can be compared to the Chimariko ya- and Salinan $a-$. Both $y$ in Chimariko (Sapir 1920a: 293) and 2- in Seri seem to be taken from singular forms. If this hypothesis is correct, the Seri second person plural prefix ma-replaced the original form, which is preserved as $q^{h} u$ - in Chimariko and as $k o$ - in Salinan, under the joint influence of second person singular $m$ - and first person plural $2 a-$.

The same pattern of $a$ for the first person and $u$ for the second person can be found in Highland Oaxaca Chontal, where subject prefixes before consonant-initial verbal stems have the following shape (Langdon 1997: 26-28):

\begin{tabular}{c|c|c}
\hline & non-past & past \\
\hline 1 sg. & ga- & ay- \\
\hline 2 sg. & do-, du- & o-/u- \\
\hline 3 sg. & di- & i- \\
\hline 1 pl. & ał- & ał- \\
\hline 2 pl. & doł-, uł- & oł- \\
\hline 3 pl. & di-, dił- & i-/ił- \\
\hline
\end{tabular}

Here, the pattern of $a$ for the first person and $u$ for the second person is extended to singular subjects as well.

${ }^{4}$ Salinan does not have uvulars in its phonological system. It also has only three vowel phonemes: $a, e$ and $o$. 
1.2. Person marking in Hokan languages is also found on nouns, where it denotes person of the possessor. Seri has the following prefixes on nouns (Marlett 2016: 320-321):

\begin{tabular}{c|c|c}
\hline & kinship terms & other possessed nouns \\
\hline 1 & 3i- & 3i- \\
\hline 1 emphatic & - & ?ati- \\
\hline 2 & ma- & mi- \\
\hline 3 & a- & i- \\
\hline absolute & $\begin{array}{c}\text { 3a- (before consonants) / } \\
\text { ?ape- (before vowels) }\end{array}$ & ?a- \\
\hline
\end{tabular}

Cf. the situation in Proto-Yuman, where the following prefixes can be reconstructed (M. Langdon's reconstruction in Marlett 2007):

\begin{tabular}{c|c}
\hline 1 & ${ }^{*} 2-$ \\
\hline 2 & ${ }^{*} \mathrm{~m}-$ \\
\hline 3 & ${ }^{*} \varnothing-$ \\
\hline absolutive & ${ }^{*} ?-$ \\
\hline
\end{tabular}

The Proto-Yuman forms have been faithfully preserved in Kiliwa, where possessive prefixes 2- ' 1 person', $m$ - ' 2 person' and $\varnothing$ - ' 3 person' are added either directly to the root, or to one of the prefixes $n^{y}$ - 'alienable' or $i$ - 'predicative' (Mixco 2013: 80-81). Cf. the following examples:

(1) yuw 'eye(s)', 2-yuw 'my eye(s)', m-yuw 'your eye(s)' (Mixco 1985: 223)

(2) 2-wa? 'house' (Mixco 1985: 223), wa? 'house, dwelling', 2-i-wa? 'my house', m-i-war 'your house' (Mixco 1985: 180)

(3) 2-mat 'earth, land, place', 2- $n^{y}-m a t$ 'my land' (Mixco 1985: 74), $m$ - $n^{y}-m a t$ 'your (sg) land' (Mixco 2013: 81).

Proto-Yuman also had an absolutive prefix *2-. Its Kiliwa reflex 2- is glossed by Mixco as '[d]ummy nominal (dn) prefix; occurring on many nouns, optionally absent in compound forms' (Mixco 1985: 223). Its presence in such unpossessed forms as 2-wa? 'house' and 2-mat 'earth, land, place' and absence from possessed forms $m$-i-wa? 'your house' and $m-n$ - $m a$ t 'your (sg) land' shows that it functions as an absolutive in Kiliwa synchronically. The Proto-Yuman absolutive * 2 - was compared to the Seri absolutive $2 a$ - by M. Langdon (Marlett 2007). The Kiliwa prefix $-i$ - in possessed non-kinship noun forms can be compared to the Seri vowel $-i-$, which distinguishes Seri possessive prefixes from subject prefixes:

\begin{tabular}{c|c|c}
\hline & possessive & subject \\
\hline 1 & 2i- & ?- \\
\hline 2 & mi- & m- \\
\hline 3 & i- & $\varnothing-$ \\
\hline
\end{tabular}

Thus, we can reconstruct a prefix of possessed nouns \#-i- and an absolutive prefix \#?a-5 at least for the common ancestor of Seri and Yuman languages.

${ }^{5}$ Following Kaufman (1989), we use \# instead of * before preliminary reconstructions. 
Now we can turn to nominal possession in Salinan. In this language "pronominal possession is morphologically marked by placement of stress, affixation and the presence of the $t$ nominal article, which also occurs as a nominalizing prefix with verbs, as the initial prefix." (Turner 1987: 69-70). Turner gives the following chart of possessive markers:

\begin{tabular}{|c|c|c|}
\hline & singular & plural \\
\hline 1 & ț-é- & ț-á-ț-e- \\
\hline 2 & $\begin{array}{l}\text { t-m-é- } \\
\text { t-o-m- }\end{array}$ & $\begin{array}{l}\text { ț-k-ó- } \\
\text { ṭ-o-k- }\end{array}$ \\
\hline 3 & $\begin{array}{c}\mathrm{t}-\mathrm{e}- \\
-\mathrm{a} \rightarrow-\mathrm{o} \\
-\mathrm{o} / \mathrm{C}_{-} \\
\text {- } \mathrm{w} \mathrm{o} / \mathrm{V}(\mathrm{l})_{-} \\
\text {penultimate stress }\end{array}$ & $\begin{array}{l}\text { all of the singular } \\
\text { plus a plural marker }\end{array}$ \\
\hline
\end{tabular}

The most regular type of possessive paradigm can be illustrated by the word sanát 'hide, skin' (Turner 1987: 74):

\begin{tabular}{|c|c|c|}
\hline & singular & plural \\
\hline non-poss. & sanát & sanaṫ-él \\
\hline 1 & ț-é-sanat & ț-á·-ț-e-sanat \\
\hline 2 & ț-m-é-sanat & ț-k-ó-sanat \\
\hline 3 & ț-e-sanát-o & ț-e-sanat-él-o \\
\hline
\end{tabular}

Here, the root is preceded by the vowel -e-, except in the second plural, where this vowel is replaced by $-0-$, cf. verbal paradigms above. This vowel, absent from the non-possessed form, can be identified with the possessed noun prefix \#-i-, reconstructed above on the basis of Yuman and Seri data. The position of the marker in the word is the same: it is inserted between the person prefixes and the root (note that the prefix -á- ' 1 pl.' is separated from -e- by an additional instance of the nominal prefix $-t-$ ).

The class of nouns without - $e$ - vowel in possessed forms can be illustrated by the inalienably possessed noun 'hand' (Turner 1987: 83):

\begin{tabular}{c|c|c}
\hline & singular & plural \\
\hline 1 & mé·n & not attested \\
\hline 2 & ț-o-m-mé·n & - \\
\hline 3 & mé·n-o & - \\
\hline
\end{tabular}

The following paradigm of the word for 'house' illustrates what Turner calls "change of initial vowel" (Turner 1987: 77):

\begin{tabular}{c|c|c}
\hline & singular & plural \\
\hline non-poss. & ț-a·m & \\
\hline 1 & t-é-ma & t-á-ț-e-·m \\
\hline 2 & t-m-é-·ma & t-k-ó-’ma \\
\hline 3 & t-e-·m-ó & t-e-·má-1-o \\
\hline
\end{tabular}


Here, the alternation of $a$ in non-possessed forms and $e$ in possessed forms is reminiscent of a similar situation in Seri. Moreover, we see here the same preservation of length as in Seri words such as 2aa-f 'nose', whose possessed forms are $1 \mathrm{sg}$. Zii-f, $2 \mathrm{sg}$. mii-f and $3 \mathrm{sg}$. ii-f (Marlett 2016: 341). Although Turner calls the alternation of $a$ and $e$ in the Salinan word for 'house' "change of initial vowel" (Turner 1987: 77), the non-possessed forms of words with this alternation in the examples adduced by Turner always have -a-: t-a·m 'house', t-áckata 'wood' (2 sg. t-m-é-kata), t-a·šax 'liver' (2 sg. ț-m-é-šsax) (Turner 1987: 76-77). This -a-might be a synchronic absolutive prefix, cognate to Seri $2 a$ - and Proto-Yuman * 2 -

The similarities with Seri do not end here. Kinship terms in Salinan do not have the $-e-$ vowel in possessed forms. Instead, they have a $3 \mathrm{sg}$. possessive prefix $2 a-$, as illustrated by the word for 'elder sister' (Turner 1987: 87):

\begin{tabular}{c|c|c}
\hline & singular & plural \\
\hline 1 & pe? & not attested \\
\hline 2 & t-o-m-pér & - \\
\hline 3 & ?a-pé-w’o & - \\
\hline
\end{tabular}

Salinan $2 a$ - 'third person singular possessive prefix on kinship terms' can be compared to Seri $a$ - 'third person possessive prefix on kinship terms'. Both are opposed to third person possessive prefix $i$ - (Seri) / $e$ - (Salinan) on non-kinship nouns (recall that Salinan has no $i$ vowel phoneme).

Let us now pass on to nominal possession morphology in Oaxaca Chontal (Waterhouse \& Parrott 1978; Turner \& Turner 1971: 326-327). In this small family, noun stems can be classified into free and bound. Free noun stems carry a definite article directly prefixed to the root. Bound stems take the prefix $-a$ - between the definite article and the root in non-possessed forms. In other words, this - $a$ - functions essentially in the same way as absolutive markers in Seri, Yuman and Salinan. When added to vowel-initial bound stems, the absolutive - $a$ - merges with the stem-initial vowel in the following way: $a+e \rightarrow a, a+i \rightarrow a y, a+u \rightarrow o$. Possessed forms of consonant-initial stems have possessive prefixes (ay- ' 1 sg.', o- '2 sg.', i- '3 sg.', at- ' 1 pl.', ot- ' 2 pl.', it- ' 3 pl.') attached directly to the stem, while vowel-initial stems either require a possessive combiner consonant $-p$ - between possessive prefixes and the root, or resort to a separate set of possessive prefixes 6 : ayn- ' 1 sg.', om- '2 sg.', Ø- ' $3 \mathrm{sg}$.', al- ' 1 pl.', ol- '2 pl.', il- ' 3 pl.'. Here, as in the verbal prefixes discussed above, vowels $a$ - in the first person and $o$ - in the second person probably descend from Proto-Hokan \#a- ' 1 pl.' and $\#\left(q^{h}\right) u_{-}$' 2 pl.', but the vowel $i$ in the third person forms most likely continues Proto-Hokan marker of possessed nouns \#-i-.

A trace of the opposition \#2a- 'absolutive' vs. \#- $i$ - 'possessed' seems to be preserved in Pomoan too. In her grammar of Eastern Pomo, McLendon (1975: 167-168) describes two "compound-linking suffixes" $-i$ - and $-a$-. The affix $-i$ - "linking the two members of a compound indicates that the second element in the compound is possessed by, or a part of, the first. It links nouns, and forms possessive prefixes which occur with kinship terms from the third person pronouns /mí·p’ 'he', /mít: 'she', and /bé·kh/ 'they'” (McLendon 1975: 167):

(4) mí.pídà.ṭ 'his wife' : dá.t’ 'wife'

míribìyle 'her husband' : báyle 'husband'

békibibàyle 'their husband'

${ }^{6}$ Preserved in Highland Chontal. 
$x \grave{a} \cdot b o\{o ́ y e l i d a ̀ \cdot t$ 'bullsnake's wife (a woman cured with a bullsnake was called this)' : xà·boróyel 'bull snake'

ká.wkî̀à 'human bones' : ká.wk 'person(s)/people', Yá 'bone'

Márakimò 'dance house hole' : Márak 'dance house', mó 'hole'

The affix - $a$ - "linking the two members of a compound indicates that the second element in the compound is composed of, or by the first. It always links nouns.” (McLendon 1975: 168):

(5) lótakà 'summer brush house (made of cut green willows with the leaves left on)' : lót 'cut green willows with leaves left on', ká 'house'

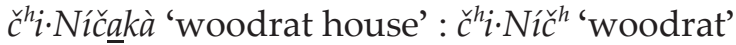

há.yaxà 'wine' : há·y 'wild grapes', xá 'water'

Another trace of the Proto-Hokan opposition \#2a- 'absolutive' vs. \#-i- 'possessed' is preserved in the Proto-Pomo lexical pair * $2 a h p^{h} a$ 'excrement' / * $2 i h p^{h} a$ 'intestines' (R. Oswalt's reconstruction, cited by H. Berman in Sapir 2001: 1053). The first word denotes an object that rarely figures as possessed, while the second word is typically possessed being a body-part. The same lexical pair is attested in Chimariko: ápxa 'excrement' / íxa 'intestines' (Sapir 2001: 1053). Kaufman reconstructs \#a-pxa ‘shit' and \#i-pxa 'guts' for Proto-Hokan (Kaufman 1989: 133).

1.3. To sum up, I propose the following reconstructions for Proto-Hokan.

1) Person/number prefixes on verbs (subject) and nouns (possessor).

\begin{tabular}{c|c|c}
\hline & sg. & pl. \\
\hline 1 & $\# 1-$ & $\#$ a- \\
\hline 2 & $\# \mathrm{~m}-$ & $\#^{\mathrm{h}} \mathrm{u}-$ \\
\hline 3 & \multicolumn{2}{|c}{ \#Ø- or \#h- } \\
\hline
\end{tabular}

In addition, kinship terms had a prefix $\# a$ - in the third person instead of $\# \varnothing$ - or $\# h$ -

2) Nominal prefixes \#-i- 'possessed' (placed before root, but after person/number prefixes; not used with kinship terms and perhaps other inalienably possessed nouns) and \#2a- 'absolutive' (mutually exclusive with possessive prefixes).

Details of derivation of daughter language systems from this reconstruction require further investigation.

\section{Lexical prefixes}

The so-called 'instrumental' verbal prefixes are a characteristic trait of many Californian languages belonging to different families; they can refer not only to instruments, but also to the manner of action (DeLancey 2008, Mithun 2007). Following DeLancey (2008), I will call them 'lexical prefixes'. Although the presence of lexical prefixes is an areal feature and as such cannot be used as an argument in favor of distant genetic relationship, such an argument can nevertheless be built on the etymological relationship of specific prefixes. Below, we will look at some cases where two or more Hokan branches show comparable lexical prefixes ${ }^{7}$.

7 According to Sapir's (1922: 217) analysis, Yana has no prefixes. Lexical prefixes of other Hokan languages correspond to Yana bound stems which must take a derivational suffix (Hinton 1988: 8-9). 
2.1. \#tu- 'with the hand/fingers'

The prefix is attested in Chimariko, Atsugewi, Yana and Pomoan. A parallel is also found in the Washo verbal prefix $d u$ - 'hands' (Jacobsen 1964: 513). Washo also has a noun á.du 'hand' (Jacobsen 1964: 260). This is one of the best parallels between Washo and Hokan.

2.1.1. The Chimariko prefix tu- 'with the hand' (Dixon 1910: 318, 329) can be illustrated by the following examples (Dixon 1910: 330).

(6) ni-tu-klucmu 'knock over with hand'

$n i-t u-k m u$ 'roll log with hand'

ni-tu-xiaxe 'rub with hand'

2.1.2. The Atsugewi prefix tu- 'the hand(s), arm(s)' (Talmy 1972: 425) can be illustrated by the following example (Talmy 1972: 443).

(7) stuspagíw 'I stuck my hand into the mud'

| s-'-w-tu-sp̉aq́-im-a |

[| s-'-w-...-a | '1, (3), factual' (inflectional affix-set), |-sp̉aq̉ | 'to move into, through mud' (root), l-im | 'thither' (directional suffix)]

2.1.3. The Proto-Pomo prefix * $d u$ - 'finger, work, action' is regularly reflected as $d u$ - in Southern Pomo, Kashaya and Northeastern Pomo, as $d u \cdot-$ in Eastern Pomo, and as 2- in Central Pomo and South Eastern Pomo (Oswalt 1976: 16; McLendon 1973: 96-97). The following examples are from Eastern Pomo, Southern Pomo, and Kashaya.

(8) Eastern Pomo (McLendon 1975: 45)

$d u \cdot d a ́ k^{h}$ 'cut finger accidentally, or split open with fingernail (as to split open nut shell to get meat)' $\left|\mathrm{du} \cdot-\mathrm{dá}-\mathrm{k}^{\mathrm{h}}\right|$

[ I-dá-I 'force open, expose, generally by interrupting the enclosing surface' (root), $\mid-\mathrm{k}^{\mathrm{h}} \mathrm{I}$ punctual aspect suffix]

(9) Southern Pomo (Walker 2013: 245)

duhnat 'to feel (peaches) to see if ripe'

$\mid$ du-hnat- $\varnothing$ |

[ I-hnat-| 'try, investigate' (root), I-Ø| perfective suffix]

(10) Kashaya (Buckley 2018)

důtáw 'feel with a finger'

$\mid$ du- 3 ta-w $\mid$

[ I-3ta-| 'seem, feel, detect with the senses' (root), $|-\mathrm{w}|$ absolutive suffix]

2.1.4. The Northern Yana bound root dô- 'do with the fingers' (Sapir 1922: 219) belongs to the class of bound roots that cannot be directly followed by inflectional suffixes. For some reason, this morpheme is not found in Sapir \& Swadesh (1960).

The forms discussed above were compared by Sapir (1917: 27; Chimariko, Eastern Pomo), Kaufman (1989: 123; Proto-Hokan \#tu-), Gursky (1995: 145; Atsugewi, Chimariko, Proto-Pomo, Washo).

2.2. \#ma- 'with the foot'.

The prefix is attested in Atsugewi, Pomoan, and Yuman (Kiliwa). 
2.2.1. The Atsugewi prefix ma- 'the foot (feet), leg(s)' (Talmy 1972: 425) can be illustrated by the following example (Talmy 1972: 444).

(11) sma·sṕáġt ${ }^{h} p u \cdot m a$ 'I stepped into a deep mud-hole'

| s-'-w-ma-sp̉aq́-tip-u--im-a |

[|s-'-w-...-a | '1, (3), factual' (inflectional affix-set), |-sp̉aq̉ | 'to move into, through mud' (root), I-tip-u.| 'into a pit' (directional suffix), |-im | 'thither' (directional suffix)]

2.2.2. Proto-Pomo * $m a$ - 'sole of foot, hoof, claw of bird; twist of wrist' is regularly reflected as Southern Pomo, Kashaya, Central Pomo and Northern Pomo ma-, as Eastern Pomo ma--, and as South Eastern Pomo m- (Oswalt 1976: 16; McLendon 1973: 97).

(12) Eastern Pomo (McLendon 1975: 49)

$m a \cdot d a ́ k^{h}$ 'cut feet on glass'

$\mid$ ma·dá-k ${ }^{\mathrm{h}} \mid$

[l-dá-| 'force open, expose, generally by interrupting the enclosing surface' (root), $\left|-\mathrm{k}^{\mathrm{h}}\right|$ punctual aspect suffix]

(13) Southern Pomo (Walker 2013: 245)

mahnatdu 'to feel around with foot (testing path)'

$\mid$ ma-hnat-ad-u |

[ I-hnat- | 'try, investigate' (root), |-ad-| 'along' (directional suffix), |-u| perfective suffix]

(14) Kashaya (Buckley 2018)

mahcháw 'push over with the bottom of the foot'

$\mid$ ma-hch $\mathrm{a}-\mathrm{w} \mid$

[l-hcha-| 'fall over, push over: of stationary, vertical long object, usually inanimate' (root), $|-\mathrm{w}|$ absolutive suffix]

2.2.3. The Kiliwa prefix m- 'foot' (Mixco 1971: 184; 1985: xvii) can be illustrated by the following example.

(15) mčhip 'slip, lose footing' (Mixco 1985: 13)

|m-čhip |

[ čhip | 'slip, slide' (root)]

2.2.4. The verbal prefix \#ma- can be compared to the Chimariko independent verb ema- 'act with the foot' (Conathan 2002: 28).

Forms discussed above were compared by Kaufman (1989: 123; Proto-Hokan \#mi- \#ma-) and Gursky (1995: 145; Atsugewi, Proto-Pomo, Kiliwa).

2.3. \#pa- 'with the mouth / by speech'.

The prefix is attested in Karuk and Pomoan.

2.3.1. The Karuk prefix pa- 'by means of the mouth' (Haas 1980: 70) can be illustrated by the following examples (Bright \& Gehr n.d.).

(16) pakátkat 'to take a taste of (something)'

| pa-kat-kat |

[l-kat I root, also found in ákat 'to taste; to taste like']

(17) panáknak '(woodpecker) to peck'

|pa-nak-nak |

[ I-nak | root, also found in iknáknak 'to knock, to tap'] 
2.3.2. Proto-Pomo * $b a$ - 'mouth, snout, beak; sound, speak, hear' is regularly reflected as Southern Pomo, Kashaya, Central Pomo, Northern Pomo and North Eastern Pomo ba-, Eastern Pomo ba--, and as South Eastern Pomo b- (Oswalt 1976: 16; McLendon 1973: 96).

(18) Kashaya (Buckley 2018)

bahná? 'ask'

|ba-hnat-? |

[ |-hnat- ' 'try, investigate, test' (root), |-3 | absolutive suffix]

(19) Kashaya (Buckley 2018)

bacéw 'grab with the mouth, beak (of bird)'

$\mid$ ba-ce-w |

[ I-ce- | 'grab, catch hold of and hold onto tightly—often something movable in order to immobilize it' (root), $|-\mathrm{w}|$ absolutive suffix]

2.3.3. The prefix \#pa- is possibly related to the Yana bound root $b a$ - 'to call, invite, shout, carry message' (Sapir \& Swadesh 1960: 43), the Karuk verb ípa. 'to say (ancient)' (Bright \& Gehr n.d.), and Highland Chontal verb di-ba-lay-2ma 'talk, converse, chat' (Turner \& Turner 1971: 61), where -lay- is apparently a suffix meaning 'over and over' (Turner \& Turner 1971: 322).

Forms discussed above were compared by Kaufman (1989: 123; Proto-Hokan \#Pa-).

2.4. \#pxu- 'by blowing'.

The prefix is attested in Atsugewi and Pomoan.

2.4.1. Atsugewi prefix $p h u$ - 'from the mouth-interior of a person-working egressively-acting on the FIGURE [e.g., by spitting out]; from matter, propelled by the mouth working egressively sailing into the FIGURE [exs.: blown breath, spit, spat-out object]' (Talmy 1972: 410, 421) can be illustrated by the following example (Talmy 1972: 455).

(20) sphop·oqúw.ehè. 'I blew the dust off my clothes'

| s-'-w-phu-puq-uww-ihiy-a |

[| s-'-w-...-a | '1, (3), factual' (inflectional affix-set), |-puq | 'for dust to move off a surface (into a cloud)' (root), |-uww | 'off from over a surface' (directional suffix), |-ihiy | 'on one's body' (directional suffix)]

2.4.2. Proto-Pomo ${ }^{*} p^{h} u$ - 'blow; burn transitive' is regularly reflected as $p^{h} u$ - in Southern Pomo and Kashaya, as $p^{h}$ - in Central Pomo, as $f u$ - in Northeastern Pomo, as $p^{h} u \cdot-$ in Eastern Pomo and as $f$ - in South Eastern Pomo (Oswalt 1976: 16; McLendon 1973: 98).

(21) Eastern Pomo (McLendon 1975: 52)

$p^{h} u \cdot \check{s}^{u} \cdot l$ 'blow (continuously)' 8

$\mid \mathrm{p}^{\mathrm{h}} \mathrm{u} \cdot-\mathrm{s}$ úu-·l|

[ I-šú-| 'force, or attempt to force through a small, narrowed, or obscured opening' (root), |-1| continuative manner suffix]

(22) Southern Pomo (Walker 2013: 248)

$p^{h} u c$ :aw 'wind to break off one (or branch just fall off)'

$\left|p^{\mathrm{h}} \mathrm{u}-\mathrm{c}: \mathrm{a}-\mathrm{w}\right|$

[ I-ć:a- | 'to break' (root), $|-w|$ perfective suffix]

8 This form is apparently cognate to Kiliwa p-sul 'blow' (Mixco 1985: 152). Kaufman (1989: 131) reconstructs $\# p^{h} u s u:(l)[s \sim \check{s}]$ 'to blow'. 
2.4.3. The prefix \#pxu- is related to the Yana bound root pu- 'to blow, suck, do with mouth' (Sapir \& Swadesh 1960: 142), Shasta verb -e'pxu?- 'blow' (Silver 1964: 171), Seri verb -apxox 'blow' (Moser \& Marlett 2010: 525), and a number of forms in other Hokan languages.

Forms discussed above were compared by Kaufman (1989: 123; Proto-Hokan \#pxu-).

2.5. \#ta- 'with instrument'.

The prefix is attested in Karuk and Yuman.

2.5.1. The Karuk prefix ta- 'with tool or implement' can be illustrated by the following examples (Haas 1980: 70; Bright \& Gehr n.d.).

(23) táyunkiv 'to pull (something) out with an instrument'

$\mid$ ta-yun-kiv|

[l-yun-| root, |-kiv| 'out through' (directional suffix)]

(24) tê.t' 'to mow'

|ta-vit |

[ I-vit I root, also found in ivit 'to detach', ikvit 'to cut']

2.5.2. A Proto-Yuman verbal prefix *t- 'by means of instrument / general causative' can be reconstructed on the basis of Yuma $t$ - 'to cause (general), to cause by means of an instrument' (Halpern 1947: 22-23), Mesa Grande Diegueño t- 'general causative' (Langdon 1970: 86), Cocopa ̌̌- 'general causative' (Crawford 1966: 115-116).

(25) Yuma (Halpern 1947: 22)

tasúly 'to gouge'

$\mid \mathrm{t}$-asúl ${ }^{\mathrm{y}}$ |

[ asúl$^{\mathrm{y} \mid}$ 'to be ripped' (root)]

2.5.3. Forms discussed above were compared by Kaufman (1989: 123; Proto-Hokan \#ta-) and Gursky (1995: 145; Karuk, Yuma).

2.6. \#ca- 'with the teeth'.

The prefix is attested in Karuk and Yuman.

2.6.1. Karuk prefix $\theta a$ - (ča- in diminutives) 'with the teeth' can be illustrated by the following examples (Haas 1980: 70; Bright \& Gehr n.d.).

(26) Eáyunkiv 'to pull out with one's teeth'

$\mid$ Oa-yun-kiv|

[ I-yun- | root, |-kiv| 'out through' (directional suffix)]

(27) Oáruprin 'gnaw through'

| $\theta$ a-ruprin |

[ I-ruprin | 'through' (directional suffix)]

The last example is a 'bipartite stem', in which a lexical prefix is combined with a locativedirectional suffix to create a verbal stem (DeLancey 2008).

2.6.2. A Proto-Yuman verbal prefix * ${ }^{-}$- 'with teeth/mouth' can be reconstructed on the basis of Kiliwa $\check{c}^{-}$'with teeth/mouth' (Mixco 1985: 2), Yuma $\check{c}$ - 'to cause with the teeth' (Halpern 1947: 22), and Jamul Tiipay $\check{c}$ - ("Nine $c h$ - stems denote actions performed with the mouth or by talking" [Miller 2001: 55]). 
(28) Kiliwa (Mixco 1985: 2)

čphu 'bite a hole'

|č-phul

[The root I-phul also occurs in mphu 'hole, cavity', xphu 'make a hole' (Mixco 1985: 119)]

2.6.3. Forms discussed above were compared by Kaufman (1989: 123; Proto-Hokan \# $₫ a=$ ) and Gursky (1995: 145; Karuk, Yuma, Kiliwa).

2.7. \#ha- 'with a long object'.

The prefix is attested in Chimariko, Pomoan, and Yuman.

2.7.1. The Chimariko prefix a- 'with a long object' (Dixon 1910: 318, 329) can be illustrated by the following examples (Dixon 1910: 329).

(29) ni-a-axiaxe 'rub with long thing (side of?)'

$n-a-k l u c m u$ 'knock over with bat'

2.7.2. Proto-Pomo *ha- 'long object thru air, leg, arm, wing' is regularly reflected as Southern Pomo and Kashaya ha- (Oswalt 1976: 16).

(30) Southern Pomo (Walker 2013: 252)

hal:it 'to wave (branch) to chase flies'

|ha-1:it- $\varnothing$ |

[ |-1:it-| 'fan' (root), |-Ø| perfective suffix]

(31) Kashaya (Buckley 2018)

haćál? 'spread legs apart'

$\mid$ ha-ćal-? |

[ I-ćal-I 'separate but remain attached at one point or along one side; hinged' (root), $|-1|$ absolutive suffix]

2.7.3. A Proto-Yuman verbal prefix * $a$-- 'long object' can be reconstructed on the basis of Yuma $a \cdot-$ 'to cause a long object' (Halpern 1947: 23), Jamul Tiipay $a \cdot-$ (“Ten stems prefixed with $a a$ denote actions performed on a long object or actions which cause an object to become long" [Miller 2001: 53-54]), and Mesa Grande Diegueño a- ("The prefix \{a·\} generally indicates that the action denoted by the root is performed on or by means of one long object (or alternately a large, hard, or sharp object). People are included in the long object class" [Langdon 1970: 80]).

(32) Mesa Grande Diegueño (Langdon 1970: 80)

a.mar 'to cover over a long object, to bury someone'

|a--maṛ $\mid$

[The root $\mid$-mar| is also found in tu-mar 'to cover over a small object' (Langdon 1970: 87)]

2.7.4. The prefix \#ha- is related to the Yana bound root ha- 'long object, affecting or by means of long object (refers to things like pole, tree, branch, hand, penis)' (Sapir \& Swadesh 1960: 88) and the Kiliwa verbal root -ha? 'set long object down' (Mixco 1985: 32).

Forms discussed above were compared by Gursky (1995: 145; Chimariko, Yuma). 
2.8. \#hi- 'with the whole body'.

The prefix is attested in Atsugewi and Pomoan.

2.8.1. The Atsugewi prefix $h i$ - 'the whole/specific part not treated by other prefix/unspecific part - of the body' (Talmy 1972: 425) can be illustrated by the following example (Talmy 1972: 445).

(33) swibhek $k^{h} k^{h}$ 'I bumped into his protruding belly'

$\mid s-'-w-h i-k^{h}$ ǔk-a|

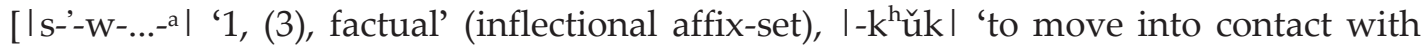
a big stomach' (root)]

2.8.2. Proto-Pomo *hi- 'with the body and not specifically an individual part' is regularly reflected as Southern Pomo and Kashaya hi- (Oswalt 1976: 16).

(34) Southern Pomo (Walker 2013: 253)

zihnat 'to weigh'

$\mid$ hi-hnat- $\varnothing$ |

[ |-hnat- | 'try, investigate' (root), |-Ø| perfective suffix]

(35) Kashaya (Buckley 2018)

hizków 'bump with the body, as when one slightly loses balance'

$\mid$ hi-3ko-w |

[ l-3ko-I 'strike, bump, knock, hit to a moderate degree' (root), $|-\mathrm{w}|$ absolutive suffix]

\section{Plural infixes}

In his review of J. A. Mason's “The Language of the Salinan Indians”, Sapir (1920b: 306) remarked: "One of the most interesting and irregular features of Salinan is the formation of the plural of nouns and of the plural and iterative of verbs. No less than a dozen distinct types and a large number of irregular formations are discussed and illustrated by Mason, the great majority of them involving a suffixed or infixed $-t-,-n-$, or $-l-$." Sapir compared Salinan infixed plurals with analogous plurals in Yana. Similar plurals occur also in Oaxaca Chontal, and possible traces of them can be found in Seri and Pomoan. For reasons of space, the discussion in the present paper will be limited to plural infixes only, although the same morphemes may function as suffixes and/or prefixes in Hokan languages. Following Sapir, we may start with Salinan infixed plurals.

3.1. The following examples of Antoniano Salinan nominal plurals from Turner (1987: 94-105) were recorded by J. P. Harrington.

$$
\begin{aligned}
& \text { (36) mošée 'flame' } \\
& \text { skóko·ye 'crest' } \\
& \text { šreneyé? 'fish hook' } \\
& \text { t-e-šxa?a·yé? 'shoe' } \\
& \text { xátep 'corpse' } \\
& \text { kó·lale? 'penis' } \\
& \text { k-šé·ke·ṭe? 'slope' } \\
& \text { mé·n 'my hand' } \\
& \text { sónon 'my leg' }
\end{aligned}
$$

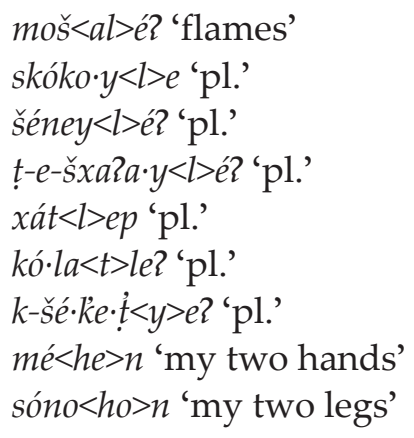


Additional examples can be found in Mason's description of Salinan (1918). Although not so reliable phonetically as forms recorded by Harrington, Mason's data are still useful.

(37) ера.'l 'tongue'

e.xiwai' 'heart'

ule.' $t$ ' 'tooth'

a.xo'L'tule'

ts'ahe.'L 'snow'
epa<'ne'>L 'pl.' (Mason 1918: 126)

e.xiw<il>ai 'pl.' (Mason 1918: 126)

le.'<he>t 'teeth' (Mason 1918: 128)

axo<ne'>L 'pl.' (Mason 1918: 128)

ts'ax<an>eL 'pl.' (Mason 1918: 133)

The - $n$ - infixes occur only before a stem-final lateral, at least in the forms given in Mason (1918). Salinan verbs also show infixation in plural forms (Turner 1987: 152-153).

(38) $k$-ló $l$ 'it burned'

$k$-á.mp 'he came out'

k-olpax 'it grew'

$k$-éšem 'he drinks'

k-ónox 'he arrives' $k$-lo<x>l 'they burned'

$k$-á.m<ele $>p$ 'they came out'

$k$-ól<ta>pax 'they grew'

$k$-éš $<t>e m$ 'they drink'

$k$-ón<l>ox 'they arrive'

In three cases, "the x infix before the t of the stem results in -xl-" (Turner 1987: 153-154).

(39) ke-yó·t-e hék 'I moved'

šót-o? 'he drove it'

šó.t 'drive it away!' ke-yo-xl-e lák 'we moved'

šó- $x l-o$ ' 'he drove them'

šo-xla? 'drive them away'

3.2. Lowland Oaxaca Chontal has several plural infixes (Waterhouse 1962: 95). The infixes -otand $-u t^{y}$ - (palatalization is automatic after high vowels in Lowland Chontal) occur with both nouns and verbs; - - - occurs only with nouns, -wat- occurs with one noun, and - $n$ - occurs with two nouns whose last consonant is $l^{y}$.

(40) inyámpáywá 'cross-beam'

xučay- 'lie'

akwé? 'man'

Rayguu- 'come'

akánóz 'woman'

kóníi 'grandchild'

sewí 'magpie'

$t^{y} u c \check{c} a$ ? 'field'

mily'á 'dog'

imul'ýa 'forked pole' in ýámp<oł>áywá-? 'cross-beams'

$x u c ̌<o t>a y-p a ́ z$ 'they lied'

$a k<u$ ty $>$ wé? 'men'

Ráyg<uł' úu-pár 'they came'

aká<ł>nó? 'women'

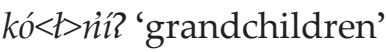

se<t>wí? 'magpies'

$t^{y} \dot{u}<w a t>c$ ća 'fields'

$m i<n>l$ 'yé? 'dogs'

$i m u<n>l^{y}-e ́$ ? 'forked poles'

Data from the Highland Oaxaca Chontal dictionary (Turner \& Turner 1971) confirm that the infixal morphology goes back to Proto-Chontal.

(41) al-ganay-? 'group of small ranches'

du-na-way-2ma 'lie down'

al-burwa 'well'

gal-gobér 'crow'

gal-cece? 'squirrel, chipmunk'

t-ejone 'knee'

t-imuko? 'underbrush, thicket'

t-aydat 'wall'

t-afiš 'waist' gal-gan<oł>áy 'pl.'

$d u-n a-w<o l>a y-\{m e$ 'pl.'

lay-bu<ł>2wá-? 'pl.'

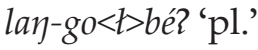

lay-ce<t>ce? 'pl.'

l-eทo<ł>né-? 'pl.'

t-imu<yol>ko? 'pl.'

t-ayd<ay>át 'pl.'

t-af<iy>iśs 'pl.' 
Salinan and Oaxaca Chontal share the following features: 1) plural infixes with a lateral, either $-l$ - or $-t-, 2)-n$ - infixes that occur only before stem-final lateral, and 3) $-y$ - infixes, rare in both language groups. The position of infixes in a stem varies not only between Salinan and Chontal, but also within each language.

3.3. Plural infixes in Yana have already been compared to Salinan infixes by Sapir (1920b: 306). The following examples are given after Sapir \& Swadesh (1960); the capitals N, C and Y stand for Yana dialects - Northern, Central, and Yahi.
(42) baazulii (C) 'bottom oak'
$b a<d 2>3 u l 2 i-w i$ 'pl.'
daati (C) 'child'
$d a<d ?>t i-w i$ 'pl.'
yaaxi $(\mathrm{Y})$ 'parent-in-law, child-in-law'
ya<d?>xii-wi 'pl.'
kuuwi (N) 'shaman, doctor'
$k<u r>$ uuwi 'pl.'
yeewi $(\mathrm{C})$ 'friend'
y<ar>iiwi 'pl.'
$\operatorname{sam}(\mathrm{si})-(\mathrm{C})$ 'to sleep'
saa<di>m(si)- 'pl.'

Jacobsen (1976: 214-215) has suggested that preconsonantal $d 2$ in Yana goes back to an earlier glottalized nasal. It is not clear whether we can compare it to - $n$-infixes of Oaxaca Chontal and Salinan, which occur only before a stem-final lateral. On the other hand, the -diinfix in $s a a<d i>m(s i)$ - can be compared to Salinan infixes with dental stop.

3.4. Seri ${ }^{9}$ has multiple ways of forming plurals on verbs and nominals ${ }^{10}$ (Marlett 1990: $532-$ 540). These include suffixation, infixation, and replacement. We will look at instances of infixation and replacement.

In a few nouns, $-x$ - is infixed before a final $-k$ that itself may be deleted by a phonological rule (Marlett 1990: 536).

(43) singular plural

$\begin{array}{lll}- \text { apak } & -a p a<x>k & \text { 'backside' } \\ \text {-ask } & -a s<x>k & \text { 'body louse' }\end{array}$

-atak $\quad-a t a<x>k,-a t a<x>-o x \quad$ 'bone'

The same pattern is also found in verbs (Marlett 1990: 540; Marlett 2016: 446).

\begin{tabular}{lllll}
\multicolumn{1}{c}{1} & \multicolumn{1}{c}{2} & \multicolumn{1}{c}{3} & \multicolumn{1}{c}{4} & \\
- -komka & $-k o m a<x>k a$ & $-k o m<x>-o x$ & $-k o m a<x>k$-am & 'noisy' \\
-iitk & $-i i t<x>k$ & $-i i t<x>-o x$ & $-i i t i<x>k$-am & 'drip'
\end{tabular}

This pattern can be compared to the Salinan examples like $k$-lo<x>l 'they burned'. Another pattern is found in a large number of verbs, with an infix -to(o)-inserted after the stem-initial vowel (Marlett 1990: 540; Marlett 2016: 437).

\footnotetext{
9 The Seri examples are taken from Moser \& Marlett (2010).

10 Seri verbs have separate stems for (1) singular subject, singular action, (2) singular subject, multiple action, (3) plural subject, singular action, and (4) plural subject, multiple action (Marlett 1990: 508). We list Seri verbs in four columns in that order, following the established practice (Marlett 1990). Note that in Marlett (2016: 442-448), "multiple action" is renamed as "imperfective aspect". Still, Marlett $(2016,443)$ states that "[a]spect morphology also in effect indicates singular versus plural direct object and singular versus plural indirect object in many cases". In other words, in such cases imperfective forms are used with plural objects. Seri frequently uses identical or similar means of marking subject plural and imperfective, so we can consider the Seri imperfective as a kind of plural.
} 
(45)

$\begin{array}{cc}1 & 2 \\ \text {-eefet-im } & \text {-eefet-am } \\ \text {-iip } & \text {-iip-tim }\end{array}$

\section{3}

$-a<$ too $>$ fet-am

$-i<t o o>p a-x^{w} \quad-i<t o o>p a-t k a$ 'trip against'

'carry on head'

This type can be compared to dental infixes of Yana and Salinan. There are some additional minor types of plural infixation in Seri, but the most interesting pattern in the light of Hokan comparison is that of replacement of root consonants. Some nouns form their plurals by changing root-final $x$ to $($ Marlett 1990: 534-535).

(46) singular

$\begin{array}{lll}\text { ášox } & \text { áš́t } & \text { 'star' } \\ \text { xékox } & x e ́ k^{w} t & \text { 'wolf' }\end{array}$

The same pattern is found in verbs (Marlett 1990: 538-539; Marlett 2016: 446).

\begin{tabular}{cllll}
1 & \multicolumn{1}{c}{2} & \multicolumn{1}{c}{3} & \multicolumn{1}{c}{4} & \\
-otexa & -otet-ka & -otet-kox & -otet-am & 'stagger' \\
-neešx & -neešit-im & -neešt-kox & -neešit-kox & 'mash' \\
-asx & -asat-im & -ast-kox & -ast-kox & 'spray'
\end{tabular}

Noteworthily, the initial $t$ of certain suffixes changes to $k$ after $t$, if that $t$ replaces $x$ in plural forms (Marlett 2016: 446-447). For example, forms like -ast-kox have a suffix with the underlying form -tox. This change does not happen after underlying $t$, which does not alternate with $x$ (Marlett 2016: 447). A search through the electronic version of the Seri dictionary (Moser \& Marlett 2010) reveals that there are no Seri words with the cluster $t x$. If we suppose that $t$ in the plural forms of verbs was originally an infix, then the replacement $x \rightarrow t$ in the plural forms can be seen as a result of a regular cluster simplification $t x>t$. Forms with the change $t>k$ could result from the following development: ${ }^{*}-a s<t>x$-tox $>{ }^{*}$-as $<t>x-k o x>-a s t-k o x$.

In another replacement pattern, root-final $t$ and $n$ change to $t$ in the plural subject forms of verb (Marlett 1990: 539; Marlett 2016: 436). In one case-the verb 'to go'-a $t$ replaced by $t$ is not root-final.

$\begin{array}{cccll}1 & 2 & 3 & 4 & \\ \text {-ooit } & \text {-oiit-im } & \text {-ooit-a } & \text {-oiit-am } & \text { 'dance' } \\ \text {-atax } & \text {-atax-im } & \text {-atx } & \text {-atax-ołka } & \text { 'go' } \\ \text {-atni } & \text {-atin-im } & \text {-att-ołka } & & \text { 'jab' }\end{array}$

A search through the electronic version of the Seri dictionary (Moser \& Marlett 2010) shows that the cluster $t n$ is banned, while the cluster $t t$ is found in two cases only: underived noun yaott 'muscle' and t-tot-tim-an imperfective form of the verb $k$-kot 'argue'. In other words, there is no obstacle for the explanation of the replacement $n \rightarrow t$ along the same lines as with $x \rightarrow t$ above: ${ }^{*}$-at< $>n$-otka $>$-att-otka. The change ${ }^{*} t n>t$ can be viewed as regular. The same explanation can be applied to the change $t>t$, if 1) the form $t$-tot-tim was created or analogically restored after the supposed change ${ }^{*} t t>t$, and 2) $t t$ was preserved word-finally, thus accounting for yaott. The infixation hypothesis can also account for the exceptional case of the verb 'go': if the replacement $t \rightarrow t$ was originally caused by some kind of suffixation, it would not target the first consonant of the root. Under the infixation account, plural forms of this verb developed in the following way: ${ }^{*}-a<t>t x>-a t x,{ }^{*}-a<t>t a x-o ł k a>-a ł a x-o t k a$. If the hypothesis sketched above is correct, $t$ that replaces $x, n$, and $t$ in Seri plural forms can be compared to the $-l$ - infix of Salinan and $-t$ - infix of Oaxaca Chontal. 
3.5 Proto-Pomo had an affix *-t- ${ }^{*}-t a-$ 'plural act' (Oswalt 1976: 22). In Southern Pomo, this morpheme is suffixed after a vowel-final verb root, but infixed if the verb root ends in a consonant (Walker 2013: 255-261). In Kashaya, the plural act affix can be infixed or suffixed depending on the final phoneme of the root (Buckley 1992: 336-340). The following example is from Southern Pomo (Walker 2013: 258).
(49) singular act
plural act
Zahlok-o
Za:lho<ta>k
'one (piece) falls off'
'(pieces) drop off'

The Pomoan plural act infix can be compared to dental infixes of Salinan, Yana and Seri.

3.6. The similarity of plural infixation systems discussed above seems too remarkable to be accounted for by a sheer coincidence. The geographical distance between Pomoan, Yana, Salinan, Seri, and Oaxaca Chontal makes areal explanation of the observed matches unlikely. Thus, the most probable scenario here is inheritance from a common parent language.

However, if infixed plurals are inherited from Proto-Hokan, why are they absent from the other Hokan branches? The answer may lie in one of the features of the Northern California linguistic area (Haas 1976). Many languages of this area lack number marking in all or most nouns. Achumawi lacks number marking in the noun (de Angulo \& Freeland 1930: 81). In Shasta, noun themes can optionally attach a collective suffix, but otherwise plural marking on nouns is absent (Silver 1966: 100-101). Chimariko lacks plural marking on nouns (Jany 2009: 71). Karuk plural suffix $-s a$ is added only to adjectives and personal nouns, and even there its presence is optional (Bright 1957: 81). In Yurok, "[i]n the great majority of nouns the same form is used both as singular and plural" (Robins 1958: 23). In Klamath, only kinship nouns have a true plural expressed by a suffix. Others can only occur with a 'distributive' reduplication (Barker 1964: 183-184). With most Maidu noun stems no plural morpheme occurs (Shipley 1964: 28). Since Karuk plural suffix and Shasta collective suffix lack cognates in other Hokan branches, while Chimariko and Achumawi do not have noun plurals at all, we may suppose that at some stage all Hokan languages of the Northern California linguistic area, except Yana, lost inherited number category in nouns under areal influence.

\section{Directional suffixes 'hither' and 'thither'}

4.1. Proto-Yuman had a pair of directional verbal suffixes that can be reconstructed as ${ }^{*} k$ 'hither' and *-m 'thither'. Their reflexes are attested in all branches of Yuman: Kiliwa, DeltaCalifornia, River, and Pai. These suffixes also acquired various secondary functions in daughter languages, e.g., marking switch reference. Below we will look at examples of the use of these suffixes in their primary function as directionals.

For Kiliwa, Mixco (1971: 139) lists two directional suffixes: - $k$ 'hither' and - $m$ 'thither'.

(50a) s-2-hin-k 'to run this way'

(50b) čan-m 'to descend that way'

In the Delta-California branch, Jamul Tiipay has directional suffixes $-k$, indicating that "the action denoted by the stem is directed towards a point of reference", and $-m$, indicating that "the action denoted by the stem is directed away from a point of reference (often the speaker)". The suffixes appear only after vowel-final roots (Miller 2001: 69-70). 
(51a) čepa-k 'to emerge, come out' (cf. čepa 'to exit')

$-u-k$ 'to look (towards reference point)'

(51b) $-a \cdot-m$ 'to go away' (cf. $-a \cdot$ 'to go')

čepa-m 'to go out, escape'

$-u-m$ 'to look (away from reference point)'

In the River branch, Yuma (Quechan) has directional suffixes - $k$ 'towards here, towards self or speaker' and $-m$ 'towards there, away from self or speaker' (Halpern 1947: 28).

(52a) apá-k 'to arrive here' (dist. pl.)

$t$-é- $k$ 'to bring something closer'

(52b) apá-m 'to arrive there' (dist. pl.)

$t-e ́ \cdot-m$ 'to move something away'

In the Pai branch, Hualapai has directional suffixes $-k$ 'toward the speaker' and $-m$ 'away from the speaker' (Watahomigie et al. 1982: 276-282).

(53a) $e:-k-k$ 'to give/receive (toward me)'

$h a:-k-k$ 'to look this way'

vo:- $k-k$ 'to come home'

(53b) e:- $m-k$ 'to send'

$h a:-m-k$ 'to look over that way'

vo:- $m-k$ 'to go home'

The Proto-Yuman directionals ${ }^{*}-k$ and ${ }^{*}-m$ have striking parallels in Chimariko, Achumawi, Atsugewi, Shasta and Karuk (Yana has a possible parallel only for ${ }^{*}-k$ ).

4.2. Howard Berman in his analysis of Sapir's Chimariko fieldnotes lists the verbal suffixes $-k$ 'motion towards here' and - $m$ 'motion towards there' (Sapir 2001: 1050-1051).

(54a) ná'awvtBık' come out!'

núwak' 'come!'

(54b) ná'awvtBrm 'go out!'

húwam 'to go'

The reliability of Sapir's data can additionally be confirmed by examples from the Chimariko text "Woman Wanders", recorded by J. P. Harrington and analyzed by Jany (2009: 217).
$x a w i$
$\check{c}^{h}$-ušehe-k-tasun
si-nda
Redwood.Indians 1SG.P-take.along-DIR-PST say-ASP
"The bad Indians took me to this country", the woman said"
(55b) nozot ř $\check{c}^{h}$-ušehe-m-derw koți-hu-t
1SG 1SG.P-take-DIR-DER run.away-CONT-ASP
'They took me off, I fled'

Although in the examples cited these suffixes surface as $-k$ and $-m$, their actual underlying form in Chimariko may rather be $-k u$ and $-m u$ (Jany 2009: 40-41, 134).

4.3. For Achumawi, de Angulo \& Freeland (1930: 94) record the derivational adverbial suffixes -ig- 'hither' and -im- 'thither'. The following examples can be cited (de Angulo \& Freeland 1930: 104). 
(56a) $d$-ím-âlù-g-ì 'to look into, the speaker being inside' $d$-ím-âdày-g-ì 'to look out of, the speaker being outside'

(56b) $d$-ímâa-lì-m-ì 'to look into an enclosure (like a room, a pot, a cavern), the person relating the action being himself outside'

$d$-ím-âdày-m-ì 'to look out of an enclosure, the speaker being inside'

The authors further illustrate the use of directionals as follows:

I am inside a room, and I say to someone who is standing outside the door: $t$-ím-âlù-à- $k$ look in here!

I am outside the door of the room, and so is my companion, to whom I say: $t$-ím-âlù-à-m look in there!

I am inside a room with another man, and I say to him: $t$-ím-âà̀y-à-m look outside!

I stand outside the door, and I say to someone inside the room: $t$-ím-âdày-à- $k$ look out this way! (ibid.).

4.4. Atsugewi has the directional suffixes $-i k$. 'hither' and -im 'thither', which can follow other directional suffixes (Talmy 1972: 40). The directional $-i k$. 'hither' can be illustrated by the following example (Talmy 1972: 441).

(57) swratwi suk:a 'I shingled the roof'

$\mid$ s-'-w-ra-ti-wi.su-ik-a

[ | s-'-w-...-a | '1, (3), factual' (inflectional affix-set), | ra- | 'a planar object sticking obliquely into/out of/against a surface' (lexical prefix), $\left|-\mathrm{t}^{\mathrm{i}}\right|$ 'for a planar object to move/belocated' (root), |-wi·su| 'to all-over a surface' (directional suffix), |-ik·| 'hither' (directional suffix)]

For -im 'thither', see examples (7) and (11) above.

4.5. Shasta has the directional suffixes $-i k \cdot a \sim-a k$ 'hither' and $-i \cdot m a$ 'thither' (Silver 1966: 174). They can be illustrated by the following examples.

(58a) kwát·ak 'He came hither' (Silver 1966: 36)

kwáska·yik·a? 'They came running hither' (Silver 1966: 157)

(58b) kwap·' $\cdot m a$ 'I threw it thither' (Silver 1966: 65)

4.6. Finally, Karuk has a directional suffix $-m u$ (-vu after vowels) 'thither, to, toward' (Bright 1957: 99).

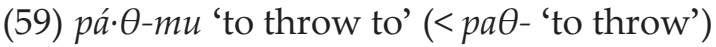

ioyíh-mu '(pl.) to arrive' (<ivyih- '(pl.) to go')

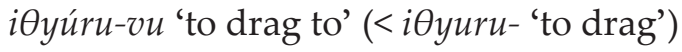

Its productive counterpart meaning 'hither' is -ra· (Bright 1957: 99-100).

(60) pá. $\theta-r a \cdot$ 'to throw hither'

However, the latter suffix is probably not very old: Bright notes that it can be identified with the verbal root na. 'to come' (ibid.). On the other hand, Karuk has another suffix with the same meaning: - uk 'hither'. According to Bright (1957: 110), "[i]t occurs freely only after derivatives in -ar̃ "to go in order to"; the resultant meaning is "to come in order to." Besides these cases, -uk is added to a very few other stems; the meaning "hither" is apparent in some cases, but completely indiscernible in others". 


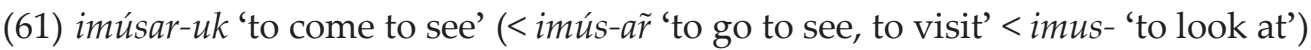
ioyíh-uk '(pl.) to come' (<ioyih- '(pl.) to go')

zíh-uk 'to do a puberty dance' (< $<$ ih 'to dance')

The non-productivity of this suffix (except after -ar̃) and the presence of derivatives with obscured semantics (like rih-uk) imply that -uk was driven out in its main function by the newly grammaticalized suffix $-r a$. 'hither'. The original situation is perhaps preserved in the pair ioyíh-uk '(pl.) to come' ivyíh-mu '(pl.) to arrive'.

4.7. The forms for 'hither' were compared by Sapir (1917: 20; Yana -ki- 'hither', Chimariko, Yuman), Dixon and Kroeber (1919: 107; Washo -k, Chimariko, Yana), de Angulo and Freeland (1930: 95; Achumawi, Atsugewi, Shasta), Jacobsen (1958: 201; Karuk, Yuma, Washo -ug -wg 'hither, in this direction', Yana -ki- 'hither'), Gursky (1966: 528; Yana, Chimariko, Palaihnihan, Yuman; 1995: 143; Achumawi, Atsugewi, Karuk, Yana, Shasta, Chimariko, Washo), Kaufman (1989: 119; Proto-Hokan \#-uky), and Berman (in Sapir 2001: 1053; Chimariko, Yuma). The forms for 'thither' were compared by de Angulo and Freeland (1930: 95; Achumawi, Atsugewi, Shasta), Jacobsen (1958: 203; Karuk, Yuma, Washo -uwe? -we? 'thither, in the other direction', Yana - $m a$ - 'there, from there'), Kaufman (1989: 119; Proto-Hokan \#- $w V[w \sim m]$ ), and Berman (in Sapir 2001: 1053; Chimariko, Yuma). Only de Angulo and Freeland (1930: 95) and Berman (in Sapir 2001: 1053) compare 'hither' and 'thither' morphemes as a set.

Chimariko, Achumawi, Atsugewi, Shasta and Karuk, but not Yuman, belong to the Northern California linguistic area (Haas 1976). One of the characteristic traits of this linguistic area is the proliferation of locative/directional verbal suffixes that frequently express such specific notions as 'into water', 'downstream', 'into the house', 'into one's mouth' etc. However, apart from the 'hither/thither' directionals discussed above, few, if any, of the locative/directional suffixes of Chimariko, Achumawi, Atsugewi, Shasta and Karuk have similar form and meaning. Commenting on the areal spread of locative/directional suffixes in the Northern California linguistic area, Mithun (2007: 157-158) remarks that, within Hokan, they appear in Pomoan, Shastan, Karuk, Palaihnihan and Yana, but are absent in Yuman, apart from the cislocative 'hither' and translocative 'thither'. Possibly, Proto-Hokan was in this respect more like Yuman than like Northern Californian languages. It can be assumed that subsequent development of Chimariko, Achumawi, Atsugewi, Shasta, Karuk and Yana in constant contact with each other led to the parallel emergence of elaborate locative/directional affix systems, but the common core of these systems-the directionals \#- $k$ 'hither' and \#- $m$ 'thither' - was inherited from Proto-Hokan.

\section{Conclusions}

There are several reasons why the comparisons analyzed in this paper are unlikely to result from areal diffusion. Cross-linguistically, bound person markers are among the least borrowed types of morphemes. It is even harder to imagine that a triple opposition of \#a- ' 3 rd person possessor on kinship terms' vs. \# $i$ - ' 3 rd person possessor on other nouns' ${ }^{11}$ vs. \#2a- 'absolutive' in Salinan and Seri may result from borrowing, especially given the geographical distance and lack of contact between these languages.

It is undeniable that areal diffusion played a role in the spread of lexical prefixes in Californian languages belonging to different families - various branches of Hokan and Penutian,

${ }^{11}$ From Proto-Hokan \#Ø- ‘3 ${ }^{\text {rd }}$ person' + \#-i- 'possessive’. 
as well as in the Numic branch of Uto-Aztecan. But the eight lexical prefixes reconstructed above are not found in Penutian or Uto-Aztecan. Besides, many of them have lexical sources in the independent verbs found in various Hokan languages.

Plural infixes are tightly integrated into morphological structures of the languages that have them. Moreover, geographical distance between Yana, Salinan, Seri and Oaxaca Chontal makes the diffusion scenario rather improbable in this case.

Finally, directionals \#- $k$ 'hither' and \#- $m$ 'thither' constitute a 'mini-paradigm', found in languages as widely separated as Chimariko and Kiliwa. Any scenario of diffusion must explain why this and other characteristic Hokan features did not penetrate languages belonging to non-Hokan families: Penutian, Uto-Aztecan, Yuki-Wappo, or Chumashan.

The list of morphological comparisons discussed above is by no means exhaustive. Gursky (1995) lists 138 comparative sets for grammatical elements, and Kaufman $(1989,2015)$ offers more than 150 reconstructions of grammatical etyma ${ }^{12}$. Kaufman (2015) also proposes a rather elaborate model of Proto-Hokan word-structure. While some of Gursky's and Kaufman's comparisons may be erroneous, many others are probably correct. Evaluation of these comparisons in the light of new descriptive data is one of the tasks necessary for the proper assessment of the Hokan hypothesis as a whole. Another necessary task is an attempt to verify sound correspondences and lexical reconstructions proposed by Kaufman (1989), as well as lexical comparisons proposed by Sapir, Gursky, and other researchers.

Attempts to reconstruct Proto-Hokan must take into account areal influences, especially in the Northern California linguistic area. While it has been frequently pointed out that areal diffusion in Northern California makes it hard to distinguish between genetic relationship and borrowing (Jany 2016), some results of the present study suggest a more optimistic outlook. Thus, if the hypotheses offered in this paper are correct, some features of Proto-Hokan (plural infixes and a simple directional system opposing 'hither' and 'thither' forms) are better preserved by languages outside of the Northern California linguistic area.

\section{References}

Angulo, Jaime de, L. S. Freeland. 1930. The Achumawi Language. International Journal of American Linguistics 6(2): 77-120.

Barker, M. A. R. 1964. Klamath Grammar. Berkeley / Los Angeles: University of California Press.

Bright, William. 1957. The Karok Language. Berkeley / Los Angeles: University of California Press.

Bright, William, Susan Gehr. Karuk Dictionary. Retrieved 08.06.2018 from http://linguistics.berkeley.edu/ karuk/ karuk-dictionary.php.

Buckley, Eugene. 1992. Theoretical Aspects of Kashaya Phonology and Morphology. PhD Thesis. University of California, Berkeley.

Buckley, Eugene. 2018. Kashaya - English Dictionary. Retrieved 08.06.2018 from Webonary.org. SIL International https://kashaya.webonary.org.

Campbell, Lyle. 1997. American Indian Languages: The Historical Linguistics of Native America. Oxford / New York: Oxford University Press.

Conathan, Lisa. 2002. Split intransitivity and possession in Chimariko. In: L. Conathan, T. McFarland (eds.). Proceedings of the 50 th Anniversary Conference, June 8-9, 2002, University of California at Berkeley: 18-31. Berkeley: Survey of California and Other Indian Languages.

Crawford, James Mack Jr. 1966. The Cocopa Language. PhD Thesis. University of California, Berkeley.

${ }^{12}$ Ironically, Campbell (1997: 296) states that “Kaufman's evidence is largely lexical”. Of course, Kaufman (1989) offers more lexical than grammatical reconstructions for Proto-Hokan, but one would search in vain for an uncontroversial language family where grammatical reconstructions outnumber lexical ones. 
DeLancey, Scott. 2008. Bipartite Verbs in Languages of Western North America. In: O. A. Osipova, E. A. Kryukova, O. S. Potanina, A. Yu. Filchenko (eds.). Sravnitel'no-istoricheskoje i tipologicheskoje izuchenije jazykov i kul'tur: sbornik tezisov mezhdunarodnoj nauchnoj konferentsii XXV-e Dul'zonovskije chtenija (26-29 ijun'a 2008 g.). Tomsk: Veter.

Dixon, Roland B. 1910. The Chimariko Indians and Language. University of California Publications in American Archaeology and Ethnology 5(5): 293-380.

Dixon, Roland B., A. L. Kroeber. 1913. New Linguistic Families in California. American Anthropologist (New Series) 15: 647-655.

Dixon, Roland B., A. L. Kroeber. 1919. Linguistic Families of California. University of California Publications in American Archaeology and Ethnology 16(3): 47-118.

Golla, Victor. 2011. California Indian Languages. Berkeley / Los Angeles / London: University of California Press.

Gursky, Karl-Heinz. 1966. Ein Vergleich der grammatikalischen Morpheme der Golf-Sprachen und der HokaSubtiaba-Sprachen. Orbis 15: 511-537.

Gursky, Karl-Heinz. 1995. Some Grammatical Evidence for the Hokan Stock. In: M. Dürr, E. Renner, W. Oleschinski (eds.). Language and Culture in Native North America: Studies in Honor of Heinz-Jürgen Pinnow: 138-153. München / Newcastle: LINCOM.

Haas, Mary R. 1976. The Northern California Linguistic Area. In: M. Langdon, S. Silver (eds.). Hokan Studies: Papers from the First Conference on Hokan Languages held in San Diego, California, April 23-25, 1970: 347-359. The Hague / Paris: Mouton.

Haas, Mary R. 1980. Notes on Karok internal reconstruction. In: K. Klar, M. Langdon, S. Silver (eds.). American Indian and Indoeuropean Studies: Papers in Honor of Madison S. Beeler: 67-76. The Hague / Paris / New York: Mouton Publishers.

Halpern, A. M. 1947. Yuma IV: Verb Themes. International Journal of American Linguistics 13(1): 18-30.

Hinton, Leanne. 1988. Yana Morphology: a Thumbnail sketch. In: J. E. Redden (ed.). Papers from the 1987 HokanPenutian Languages Workshop and Friends of Uto-Aztecan Workshop, Held at University of Utah, Salt Lake City, June 18-21, 1987: 7-16. Carbondale: Southern Illinois University, Department of Linguistics.

Hinton, Leanne, Margaret Langdon. 1976. Object-subject Pronominal Prefixes in La Huerta Diegueño. In: M. Langdon, S. Silver (eds.). Hokan Studies: Papers from the First Conference on Hokan Languages held in San Diego, California, April 23-25, 1970: 113-128. The Hague / Paris: Mouton.

Jacobsen, William H., Jr. 1958. Washo and Karok: An Approach to Comparative Hokan. International Journal of American Linguistics 24(3): 195-212.

Jacobsen, William H., Jr. 1964. A Grammar of the Washo Language. PhD Thesis. University of California, Berkeley.

Jacobsen, William H., Jr. 1976. Observations on the Yana Stop Series in Relationship to Problems of Comparative Hokan Phonology. In: M. Langdon, S. Silver (eds.). Hokan Studies: Papers from the First Conference on Hokan Languages held in San Diego, California, April 23-25, 1970: 203-236. The Hague / Paris: Mouton.

Jany, Carmen. 2009. Chimariko Grammar: Areal and Typological Perspective. Berkeley / Los Angeles / London: University of California Press.

Jany, Carmen. 2016. Hokan Languages. In: Oxford Research Encyclopedia of Linguistics. Online at: http://linguistics.oxfordre.com/view/10.1093/acrefore/9780199384655.001.0001/acrefore-9780199384655-e-19. doi: 10.1093/acrefore/9780199384655.013.19.

Kaufman, Terrence. 1989. A Research Program for Reconstructing Proto-Hokan: First Gropings. In: S. DeLancey (ed.). Papers from the 1988 Hokan-Penutian Languages Workshop, Held at the University of Oregon, Eugene, Oregon, June 16-18, 1988: 50-168. Eugene, OR: Department of Linguistics, University of Oregon.

Kaufman, Terrence. 2015. Some Hypotheses Regarding Proto-Hokan Grammar. Retrieved from https://www.albany.edu/ ims/pdlma/2015\%20Publications/Kaufman-some\%20hypotheses\%20regarding\%20protoHokan\%20grammarrevd2015.pdf.

Langdon, Margaret. 1970. A Grammar of Diegueño: The Mesa Grande Dialect. Berkeley / Los Angeles / London: University of California Press.

Langdon, Margaret. 1997. Notes on Highland Chontal Internal Reconstruction. In: L. Hinton (ed.). The Hokan, Penutian E J.P. Harrington Conferences And The Mary R. Haas Memorial, June 28-29, 1996, University of California at Berkeley: 25-34. Survey of California and Other Indian Languages.

Marlett, Stephen A. 1990. Person and Number Inflection in Seri. International Journal of American Linguistics 56(4): 503-541. 
Marlett, Stephen A. 2007. Las relaciones entre las lenguas "hokanas” en México: ¿cuál es la evidencia? In: C. Buenrostro, S. Herrera Castro, Y. Lastra, J. J. Rendón, O. Schumann, L. Valiñas, M. A. Vargas Monroy (eds.). Clasificación de las lenguas indígenas de México. Memorias del III Coloquio Internacional de Lingüística Mauricio Swadesh: 165-192. México: Instituto de Investigaciones Antropológicas, Universidad Nacional Autónoma de México e Instituto Nacional de Lenguas Indígenas.

Marlett, Stephen A. 2016. Cmiique Iitom: the Seri language. Retrieved from https://arts-sciences.und.edu/summerinstitute-of-linguistics/faculty/marlett-steve/serigrammar.pdf.

Mason, J. Alden. 1918. The Language of the Salinan Indians. University of California Publications in American Archaeology and Ethnology 14(1): 1-154.

McLendon, Sally. 1973. Proto Pomo. Berkeley / Los Angeles / London: University of California Press.

McLendon, Sally. 1975. A Grammar of Eastern Pomo. Berkeley / Los Angeles / London: University of California Press. Miller, Amy. 2001. A Grammar of Jamul Tiipay. Berlin / New York: Mouton de Gruyter.

Mithun, Marianne. 2007. Grammar, Contact and Time. Journal of Language Contact 1(1): 144-167. doi: $10.1163 / 000000007792548378$.

Mixco, Mauricio J. 1971. Kiliwa Grammar. PhD Thesis. University of California, Berkeley.

Mixco, Mauricio J. 1978. Cochimi and Proto-Yuman: Lexical and Syntactic Evidence for a New Language Family in Lower California. Salt Lake City, Utah: University of Utah Press.

Mixco, Mauricio J. 1985. Kiliwa Dictionary. Salt Lake City, Utah: University of Utah Press.

Mixco, Mauricio J. 2013. Introduction to the Kiliwa Language. Amerindia 37(1): 53-86.

Moser, Mary Beck, Stephen A. Marlett. 2010. Comcaac quih yaza quih hant ihiip hac: cmiique iitom - cocsar iitom - maricaana iitom = Diccionario seri - español - inglés: con índices español - seri, inglés - seri y con gramática (2a ed.). Hermosillo, Son.: Universidad de Sonora \& Plaza y Valdés Editores.

Oswalt, Robert L. 1976. Comparative Verb Morphology of Pomo. In: M. Langdon, S. Silver (eds.). Hokan Studies: Papers from the First Conference on Hokan Languages held in San Diego, California, April 23-25, 1970: 13-28. The Hague / Paris: Mouton.

Robins, R. H. 1958. The Yurok Language: Grammar, Texts, Lexicon. Berkeley / Los Angeles: University of California Press.

Sapir, Edward. 1917. The Position of Yana in the Hokan Stock. University of California Publications in American Archaeology and Ethnology, 13(1): 1-34.

Sapir, Edward. 1920a. A Note on the First Person Plural in Chimariko. International Journal of American Linguistics 1(4): 291-294.

Sapir, Edward. 1920b. [Review of:] Mason, J. Alden. - The Language of the Salinan Indians. University of California Publications in American Archaeology and Ethnology, vol. 14, no. 1, pp. 1-154. Berkeley, 1918. International Journal of American Linguistics 1(4): 305-309.

Sapir, Edward. 1922. The Fundamental Elements of Northern Yana. University of California Publications in American Archaeology and Ethnology 13(6): 215-234.

Sapir, Edward. 1925. The Hokan Affinity of Subtiaba in Nicaragua (Conclusion). American Anthropologist (New Series) 27(4): 491-527.

Sapir, Edward. 2001. Chimariko Linguistic Material. Edited by Howard Berman. In: V. Golla, S. O'Neill (eds.). The Collected Works of Edward Sapir XIV: Northwest California Linguistics: 1039-1076. Berlin: Mouton de Gruyter.

Sapir, Edward, Morris Swadesh. 1960. Yana Dictionary (ed. by Mary R. Haas). Berkeley / Los Angeles: University of California Press.

Shipley, William F. 1964. Maidu Grammar. Berkeley / Los Angeles: University of California Press.

Silver, Shirley. 1964. Shasta and Karok: A Binary Comparison. In: W. Bright (ed.). Studies in Californian Linguistics: 170-181. Berkeley / Los Angeles: University of California Press.

Silver, Shirley. 1966. The Shasta Language. PhD Thesis. University of California, Berkeley.

Talmy, Leonard. 1972. Semantic Structures in English and Atsugewi. PhD Thesis. University of California, Berkeley.

Turner, Katherine. 1987. Aspects of Salinan Grammar. PhD Thesis. University of California, Berkeley.

Turner, Paul, Shirley Turner. 1971. Dictionary: Chontal to Spanish-English, Spanish to Chontal. Tucson, Arizona: The University of Arizona Press.

Walker, Neil Alexander. 2013. A Grammar of Southern Pomo, An Indigenous Language of California. PhD Thesis. University of California, Santa Barbara. 
Watahomigie, Lucille J., Jorigine Bender, Akira Yamamoto. 1982. Hualapai Reference Grammar. Los Angeles: American Indian Studies Center, UCLA.

Waterhouse, Viola Grace. 1962. The Grammatical Structure of Oaxaca Chontal. Bloomington: Indiana University Research Center in Anthropology, Folklore, and Linguistics.

Waterhouse, Viola Grace, Muriel Parrott. 1978. Oaxaca Chontal Noun Inflection and Classification. In: J. E. Redden (ed.). Proceedings of the 1977 Hokan-Yuman Languages Workshop, Held at the University of Utah, Salt Lake City, June 21-23, 1977: 54-66. Carbondale, Illinois: Department of Linguistics, Southern Illinois University.

Zamponi, Raoul. 2017. First-person $n$ and second-person $m$ in Native America: a fresh look. Italian Journal of Linguistics 29(2): 189-230. doi: 10.26346/1120-2726-113

\section{М. А. Живлов. О некоторых морфологических параллелях между языками хока}

В статье детально рассматривается ряд морфологических параллелей между ветвями гипотетической семьи хока (Северная Америка). Анализируются следующие области морфологии хоканских языков: 1) глагольные показатели лица/числа субъекта, а также именные показатели лица/числа посессора, 2) так называемые лексические префиксы, обозначающие инструмент или образ действия, 3) инфиксы - показатели множественного числа и 4) глагольные направительные суффиксы со значениями 'сюда' и 'туда'. В статье показывается, что рассматриваемые морфологические параллели убедительнее объясняются как унаследованные из общего праязыка, чем как возникшие в результате контактов.

Ключевые слова: языки хока, америндские языки, историческая морфология, языковое родство и языковые контакты. 